group has been reduced to a mercaptan and then with the elimination of hydrogen sulphide the following body was obtained.

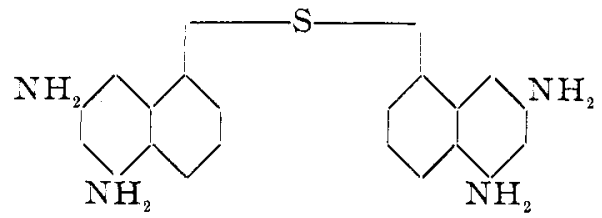

In conclusion I wish to thank Professor L. Gattermann for valuable assistance and Professor Carl Duisberg for his kindness in supplying large quantities of raw materials for the experiments.

Germantown. Philadelphia

[CONTRIBUTION FROM THE CHEMICAL IABORATORY OF THE UNIVERSITY OF ILI,INOIS].

\title{
AN IMPROVED METHOD FOR THE PREPARATION OF ALKYL CHLORIDES.
}

William M. DEHN aNi GRaxt 'T. Davis.

Received July 2, $590 \%$

On account of the variety of reactions into which they enter, the alky! halides and their preparation are of especial interest and importance. Though quite satisfactory methods for the preparation of the bromides and iodides are in common use, the present methods used for preparing the corresponding chlorides are open to serious objections, principally on account of the smallness of yields. The necessity of preparing considerable quantities of a number of higher alkyl chlorides for another line of research led us to investigate more closely the methods hitherto employed, in order to determine the best conditions and methods for the preparation of these compounds.

The first alkyl chloride was prepared in 759 by Rouelle, who treated ethyl alcohol with the chlorides of sulphur, antimony, tin, iron, bismuth, and aluminum respectively. In I80I Basse prepared the same chloride by treating alcohol with gaseous hydrochloric acid and, ${ }^{1}$ modified by the addition of zinc chloride ${ }^{2}$ in the case of methyl and ethyl alcohols and by heating in sealed tubes the higher alcohols saturated with gaseous hydrochloric acid, this remained the favorite method for many years.

In 87 I Pierre and Puchot, ${ }^{3}$ working with propyl and butyl alcohols, discarded the reactions in sealed tubes, in favor of the reaction of phosphorus pentachloride with alcohols ${ }^{4}$, and this method of preparation, to-

1 Balard, Ann. 52, 312; Zincke, Ann. 152, 4; Rossi, An1. I59, 72; Cross, Ann. 189, 3; Butlerow, Ann. 189, 5I; Rohn, Ann. 190, 312; Brocket, An11. 77 I0, 384; Kaschirscky, Russ. Ber. 13, 90.

"Groves, Ann. 174, 372. Krüger J. pr., Chem. (2) 14, 195.

"Ann. 163, 265.

- Cahours, Ann, 37, 164; Borris, Ann. 92, 398; Limpricht, Ann. 103, 81; Butlerow, An11. 177, I83; Pieverling, Ann. 183, 348; Winogradow, Ann. 191, I3I, Wyschnegradsky, Ann. 190, 336; Saytzen, Ann. 179, 321 ; Butlerow, Bull. soc. chim. 5, 24; LeBel. Bull. soc. chim. 25, 546; Henry; Bull. soc. chin1. 41, 363; Mourgues, Ber. 23, 658; Fawosky, Russ. Ber., 19, 425; Grigorowitsch, Pawlow, Russ. Ber. 23, i66. 
gether with its modifications in the use of phosphorus trichloride ${ }^{1}$ and phosphorus oxychloride ${ }^{2}$, is most commonly recommended in the text books, although Malbot ${ }^{3}$ reported "a quantitative yield" of the active amyl chloride when he heated in a sealed tube, alcohol first saturated with gaseous hydrochloric acid and then mixed with one half its volume of fuming aqueous acid. Other methods which have been employed with less success involve the action of chlorine on paraffin hydrocarbons ${ }^{4}$ and the action of hydrochloric acid on olefin hydrocarbons. ${ }^{5}$

The general objections to these methods are found to be either the smallness of the yields or the inconvenience of using sealed tubes. Special objection to the use of phosphorus pentachloride was found in the violence of its action, and the tendency to form phosphorus-containing by-products. The trichloride and oxychloride, though less reactive, yield excessive quantities of these by-products which were found to be either phosphorus esters. ${ }^{6}$ or the suboxide of phosphorus ${ }^{i}$, the latter resulting from the action of the phosphorus chloride on the phosphorous acid first formed. Efforts to avoid these secondary actions, finally resulted in a very satisfactory method, the reaction being in the sense of the equation:

$\mathrm{PCl}_{3}+\mathrm{ZnCl}_{2}+{ }_{3} \mathrm{ROH}=3 \mathrm{RCl}+2 \mathrm{HCl}+\mathrm{ZnHPO}_{3}$.

With proper precautions a 94 per cent. yield of propyl chloride was obtained :

Preparation of Propyl Chloride.-A zinc chloride solution, prepared by dissolving zinc in commercial hydrochloric acid, was evaporated until a thermometer in the liquid registered $240^{\circ}$. The hot mass (I50 g.) was poured into a one-liter, round bottom Jena flask, and turned while cooling so as to leave exposed the maximum surface of solidified zinc chloride. The flask was placed upon a water bath and fitted with a suitable rubber stopper through which were adjusted two dropping funnels and a distilling column. One dropping funnel was arranged so as to admit phosphorus trichloride to the lowest level of the flask, while the other funnel dropped the alcohol upon the surface of the reaction-mixture. The distilling column, carrying a thermometer, was connected to an up-

${ }^{1}$ Jaraschinko, Chem. Centr., I887, II, 334.

${ }^{2}$ Silver, Ber. 6, 35 .

${ }^{3}$ Bull. soc. chim. (3), 1, 603 ( I888).

4 Aschan, Ber, 31, I802; Berthelot, Ann. chim. phys.(3) 52, 97 ; Cahours, Jahresberichte, 1863, 524; Schorlemmer, Ann. 144, 187; Ann. 161, 268; Hudson, Am. Chem. J. $19,245,247$.

5 Berthelot, Ann. I27, 7 r; Würtz, Ann. chin. phys. (4) 3, I6r; Saytzen, Ann. I79, 32 I, Pawlow, Ann. 196, I 24; Kondakow, Russ. Ber. 28, 790; Scheschukow, Russ. Ber. 17, 509 .

6 Wurtz, Ann. 58, 72; Schiff, Ann. 103, 164; Menschutkin, Ann. 139, 343; Chambon, Jahresberichte, 1876, 205. 1032.

${ }^{7}$ Kraut, Ann. 158, 332; Pantier, Compt. rend. 76, 49; Risson, Compt. rend. 125, 
right coil-condenser into which water from a dropping funnel was admitted, so as to condense the gaseous hydrochloric acid evolved by the reaction; the end of the condenser was connected with an ordinary filter flask surrounded by ice water. When the apparatus was adjusted, onehalf (I50 g.) of the phosphorus trichloride was admitted to the flask and, while heating gently, one-third ( $90 \mathrm{~g}$.) of the alcohol was admitted drop by drop. After this portion was added, the remainders of the phosphorus trichloride and the alcohol were admitted simultaneously and at equivalent rates; fually the water-bath was remored and the reactionflask was heated with a constantly moving flame until the distillation was complete. The mixture of oil and water in the receiver was separated; the oil was dried with calcium chloride and distilled. From $270 \mathrm{~g}$. of propyl alcohol were obtained $330 \mathrm{~g}$. of propyl chloride, equal to 94 per cent. of the theoretical quantity.

This method of preparation of alkyl chlorides was next applied to isobutyl and isoamyl alcohols (See experiments 9 and 8 of table) but the yields were found to be only 60 per cent. and 75 per cent. respectively.

Since Grove did not report clearly the yields obtained when he treated alcohols with zine chloride and hydrochloric acid, it was decided to determine the relative merits of his and the above-described methods. In the case of isoamyl alcohol, after extracting the reaction-product with ether and then distilling, 37 per cent. of isoamyl chloride and 28 per cent. of other alkyl chlorides were obtained. Eridently Grove's method is conducive to secondary reactions, and the yields are quite unsatisfactory.

The method of Malbot ${ }^{2}$ was next tried : propyl, isobutyl and isoamyl alcohols respectively were saturated with hydrochloric acid gas, mixed with an equal volume of fuming hydrochloric acid, sealed in tubes, and heated several hours at $100^{\circ}-105^{\circ}$. The yields were equal to 82.85 per cent. of the theory. Since Malbot's reaction :

\section{$\mathrm{ROH}+\mathrm{HCl} \leftrightarrows \mathrm{RCl}-\mathrm{H}_{2} \mathrm{O}$.}

is reversible by saponification, it can never become quantitative. This is confirmed by the following experiment. A mixture of equimolecular quantities of propyl chloride and water was heated for several hours at $100^{\circ}-105^{\circ}$; the aqueous layer was found by titration to contain 16 per cent. of chlorine as hydrochloric acid, while the weight of the unchanged propyl chloride was 84 per cent.

Efforts were next made to improve the yields of these higher alkyl chlorides by modification of the phosphorus trichloride method employed with propyl alcohol. From consideration of it and the following experiments, the conclusions were finally drawn that maximum yields can be obtained and secondary reactions, as evidenced by the formation

${ }^{2}$ Bl. (13) I (603). 
of isomeric alkyl chlorides, alkylated phosphorus compounds and olefins, can be avoided: ( $I$ ) when the gaseous hydrochloric acid of the distillate is completely absorbed by water, (2) when the phosphorus trichloride is brought into intimate contact with the zinc chloride and alcohol, (3) when the temperature of the reaction is elevated above the boiling point of the desired chloride and (4) when the zinc chloride is completely dissolved early in the reaction.

These and other points are illustrated in the following table of experiments :

\begin{tabular}{|c|c|c|c|c|c|c|c|c|}
\hline & & Quan & tities $Y$ & Yields $\mathrm{fr}$ & om A1 & lcohol & Flast & \\
\hline $\begin{array}{l}\text { Ex- } \\
\text { peri- } \\
\text { ment }\end{array}$ & $\begin{array}{l}\text { Alcohol } \\
\text { Kind }\end{array}$ & $\begin{array}{l}\text { Taken } \\
\mathrm{PCl}_{3} \mathrm{R}\end{array}$ & $\begin{array}{l}1 \text { for } \\
\mathrm{OH}_{\mathrm{H}} \\
\mathrm{ZnCl}_{2}\end{array}$ & $\underset{\mathrm{RCl}}{\text { Desired }}$ & $\begin{array}{l}\text { Total } \\
\mathrm{RCl}\end{array}$ & $\begin{array}{l}\text { Other } \\
\text { Prod- } \\
\text { ucts }\end{array}$ & $\begin{array}{l}\text { Heate } \\
\text { Whil } \\
\text { Mixin }\end{array}$ & $\begin{array}{l}\text { Observations } \\
\text { and } \\
\text { Remarks }\end{array}$ \\
\hline I & A & I. $8^{\circ}$ & I.8 & 63 & 74 & 8 & Yes & $\begin{array}{l}\mathrm{ROH} \text { and } \mathrm{ZnCl}_{2} \text { in contact } 18 \mathrm{hrs} \text {; un- } \\
\text { condensed cases collected over } \mathrm{H}_{2} \mathrm{O} \text {. }\end{array}$ \\
\hline 2 & A & 3.0 & 3.0 & 49 & & & Yes & The gaseous $\mathrm{HCl}$ was condensed. \\
\hline 3 & A & $5 \cdot 3$ & 2.6 & I6 & 36 & $4 \mathrm{I}$ & Yes & $\begin{array}{l}\text { Heated } 2 \text { hrs. under reflux before } \\
\text { distilling. }\end{array}$ \\
\hline 4 & A & I.O & 1.3 & 46 & 56 & 15 & No & Some $\mathrm{ZnCl}_{2}$ remained undissolved. \\
\hline 5 & $\mathbf{P}$ & 1.5 & I.O & 74 & 74 & & Yes & $\begin{array}{l}\mathrm{PCl}_{3} \text { added to } \mathrm{ZnCl}_{2} ; \text { then } \mathrm{ROH} \\
\text { dropped in; gaseous } \mathrm{HCl} \text { condensed. }\end{array}$ \\
\hline 6 & $P$ & I.5 & 0.5 & 36 & 36 & & No & $\begin{array}{l}\text { Mixture treated with water; oil dried } \\
\text { and distilled; } \mathrm{HCl} \text { condensed. }\end{array}$ \\
\hline 7 & $\mathbf{P}$ & 1.6 & 0.6 & 94 & 94 & & Yes & See page 1329 \\
\hline 8 & A & $\mathrm{I} .5$ & 0.3 & & 75 & o & Yes & $\begin{array}{l}\text { No fraction above } 105^{\circ} \text {; small quan- } \\
\text { tity of tertiary } \mathrm{RCl} \text {. }\end{array}$ \\
\hline 9 & B & I. 5 & 0.6 & & 60 & 0 & Yes & Some tertiary $\mathrm{RCl}$. \\
\hline 10 & A & I. 5 & 0.5 & 68 & 88 & o & Yes & See page 1332 . \\
\hline II & B & 1.5 & 0.6 & & 85 & ० & Yes & $\begin{array}{l}\text { Same as experiment to but too much } \\
\mathrm{ZnCl}_{2} \text { used. }\end{array}$ \\
\hline I2 & A & 1.0 & $\begin{array}{l}\mathrm{CaCl}_{2} \\
3.0\end{array}$ & I4 & 53 & & Yes & $\begin{array}{l}\text { Heated under reflux for } 2 \text { hrs. before } \\
\text { distilling. }\end{array}$ \\
\hline 13 & A & 1.0 & $\begin{array}{l}\mathrm{AlCl}_{3} \\
\mathrm{I} .0\end{array}$ & & 50 & Yes & No & $\begin{array}{l}\text { Large yields of high boiling products } \\
\left(200^{\circ}+\right) .\end{array}$ \\
\hline & & & $\mathrm{AlCl}_{3}$ & & & & & \\
\hline I4 & A & 0.75 & $\begin{array}{l}0.3 \\
\mathrm{~A} 1\end{array}$ & & 60 & & No & Same as experiment I 4 . \\
\hline I5 & $P$ & 1.0 & $\begin{array}{l}1.0 \\
\mathrm{ZnO}\end{array}$ & 60 & & Yes & No & $\begin{array}{l}\text { Some } \mathrm{RCl} \text { carried off by the evolved } \\
\text { bydrogen. }\end{array}$ \\
\hline I6 & B & 1.5 & 0.6 & & 54 & & Yes & \\
\hline
\end{tabular}


The kinds of alcohols indicated are isoamyl (A), normal propyl (P) and isobutyl (B). In all cases the calculation of quantities of materials had $3 \mathrm{ROH}$ as the basis; the yields, usually the result of one distillation, were calculated on the basis of the alcohol used.

A study of the above experiments shows that zinc chloride in the proportions of the equation :

$$
3 \mathrm{PCl}_{3}+3_{3} \mathrm{ZnCl}_{2}+6 \mathrm{ROH}=6 \mathrm{RCl}+6 \mathrm{HCl}+\mathrm{Zn}_{3}\left(\mathrm{PO}_{3}\right)_{2}
$$

is excessive and, in fact, is positively injurious, depressing the yields and giving rise to higher-boiling condensation products. Therefore the reaction involved must be according to the equation:

$$
\mathrm{PCl}_{3}+\mathrm{ZnCl}_{2}+{ }_{3} \mathrm{ROH}=\mathrm{ZnHPO}_{3}+{ }_{3} \mathrm{RCl}+2 \mathrm{HCl}
$$

or more probably (see experiment 7 ) is:

$$
2 \mathrm{PCl}_{3}+\mathrm{ZnCl}_{2}+6 \mathrm{ROH}=\mathrm{Zu}\left(\mathrm{HPO}_{3}\right)_{2}--6 \mathrm{RCl}+2 \mathrm{HCl} \text {. }
$$

A comparison of experiments ( $\mathrm{I}$ ) and (4) shows that it is quite necessary to use an excess of phosphorus trichloride; owing to its volatility, some always escapes reaction.

The advautage of heating the mixture while adding the reagents is shown in experiments (6) and (7). The superiority of zinc chloride over the other condensing agents used is sufficiently indicated in the table. The use of calcium chloride is characterized by the formation of a preponderance of tertiary chloride; this behavior certainly merits further study. Aluminum chloride yielded quantities of high-boiling products whose composition was not determined.

Since, in his preparation of methyl and ethyl chlorides, Grove found that a concentrated solution of zinc chloride was as efficient as the fused solid, and, as was shown abore, intimate contact of zinc chloride is of great advantage, this modification of the phosphorus trichloride method was tried with the higher alcohols.

Preparation of Isoam!!' Chioride. - A $500 \mathrm{cc}$. round-bottom flask containing 90 grams of phosphorus trichloride was connected with the apparatus described under the preparation of propyl chloride. One of the dropping funnels held ${ }^{2} 32$ grams of isoamyl alcohol; the other, 50 grams of warm zinc chloride solution (boiling $150^{\circ}-160^{\circ}$ ). The alcohol was Grst dropped in as rapidly as possible while shaking the reactionflask and warming gently; then the zinc chloride ${ }^{2}$ was run in, care being exercised that its immediate solution was effected.

The mixture was distilled in the manner described above; the yield of washed and dried oil was 140 grams or 88 per cent. of the theory. One fractionation gave $\mathrm{I} 6$ grams boiling $80^{\circ}-95^{\circ}$ and I 7 grams boiling $95^{\circ}$. $105^{\circ}$-evidently some isomeric chloride was formed.

Preparation of Isobutyl Chloride.-In the same manner, with 222 grams

'Excess of zinc chloride should be avoided; when the evident reaction with the zinc chloride ceases, its further addition should be discontinued. 
of isobutyl alcohol, 204 grams of phosphorus trichloride and 92 grams of zinc chloride, a yield of 85 per cent. of washed and dried oil was obtained. In this experiment the quantity of zinc chloride used was somewhat excessive. Substituting liquid for solid zinc chloride and changing the manner of mixing the three substances as described above, while enhancing the yields with amyl and butyl alcohols, really depressed the yield with propyl alcohol; evidently the increased temperature of the reactions volatilized unchanged alcohol.

From consideration of all of the above experiments, the conclusion is drawn that alkyl chlorides can be prepared with maximum yields by treating alcohols with phosphorus trichloride and anhydrous zinc chloride.

The Mechanics of the $\mathrm{ROH}-\mathrm{PCl}_{3}-\mathrm{ZnCl}_{2}$ Reaction. It might superficially be supposed that the equation:

$$
6 \mathrm{ROH}+{ }_{2} \mathrm{PCl}_{2}=\mathrm{Zn}\left(\mathrm{H}_{2} \mathrm{PO}_{3}\right)_{2}+6 \mathrm{RCl}+2 \mathrm{HCl}
$$

or, more in detail, the equations:

$$
\begin{aligned}
\mathrm{FCl}_{3}+3 \mathrm{ROH} & =\mathrm{H}_{3} \mathrm{PO}_{3}+{ }_{3} \mathrm{RCl} \\
2 \mathrm{H}_{3} \mathrm{PO}_{3}+\mathrm{ZnCl}_{2} & =\mathrm{Zn}\left(\mathrm{H}_{2} \mathrm{PO}_{3}\right)_{2}+{ }_{2} \mathrm{HCl}
\end{aligned}
$$

sufficiently indicate the chemical mechanics involved; however, during the progress of the experiments it became more and more evident, that when these three substauces are mutually brought into contact, inter. mediate compounds are invariably formed. Evidence for this view was seen in the following: When the reaction-product was treated with water and then extracted with ether (See experiment 6 and Grove's experiment, page 1330 ), a stable oil was obtained; on distilling, alkyl chloride and hydrochloric acid were given off, then at $\mathrm{IO}^{\circ}$ a sudden violent decomposition took place, alkyl chloride and olefin were expelled and a white zinc and phosphate-containing solid separated. The hydrochloric acid, alkyl chloride, and olefin could not have been present in the oil, therefore these compounds must have been formed by the decomposition of some complex intermediate product.

Let us now consider the possibilities of the problem indicated in the diagram :

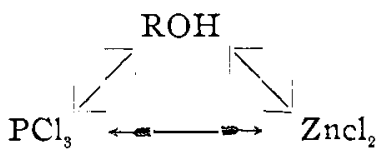

In the first place $\mathrm{PCl}_{3}$ has no effect on $\mathrm{ZnCl}_{2} ; \mathrm{ROH}+\mathrm{ZnCl}_{2}$ gives at high temperatures' abundant yields of olefin, polmerized olefin and other compounds, but at low temperature, products indicated by $\mathrm{ROH} . \mathrm{ZnCl}_{2}$ or by the equation :

$$
\mathrm{ROH}+\mathrm{ZnCl}_{2}=\mathrm{ROZnCl}+\mathrm{HCl}
$$

Collateral evidence of the formation of these intermediate molecular

'Silva Jahresberichte 1873, 322; Nevoli, Bull.soc. chim. 24, I22; LeBel and Greene, Am. Chem. J. 2, 23; Balard, Ann. chim. phys. (3) 12, 320; Franklard, Ann. 74, 4; Wysch negradsky, Russ. Ber. 9, I92; Eltekow, do. 9, 222; Kondakow, do. 24, II3.

${ }^{2}$ Walter, J. pr. Chem. 59, 41. 
compounds may be deduced by considering the ease with which alcohols form addition-products with other metallic chlorides good examples of which for instance, are $\mathrm{SnCl}_{4} \cdot 2 \mathrm{C}_{2} \mathrm{H}_{5} \mathrm{OH}$ and $\mathrm{SnCl}_{4} \cdot 2 \mathrm{C}_{2} \mathrm{H}_{11} \mathrm{OH}$. When we treated stannic chloride with an excess of propyl alcohol we abtained no propyl chloride but a liquid boiling at $145^{\circ}$.

End-products of the $\mathrm{PCl}_{3} \hookleftarrow \mathrm{ROH}$ combinations have already been mentioned; their intermediate prolucts, theoretically considered, may be many ; these intermediate products may give directly by heating or under the influence of zinc chloride and heat, the required alkyl chloride. A study of these intermediate products will be made.

CRIBANA, ILL.

\section{ON THE COMBINING POWER OF CASEIN WITH CERTAIN ACIDS.}

BY J. H. LONG.

Received July is, igo\%.

In several recent papers I have shown the amount of different alkalies which may be combined with a given weight of casein to form salts, ${ }^{1}$ and have also pointed out the behavior of hydrochloric acid in combining with the products of casein hydrolysis brought about by prolonged digestion in presence of pepsin, with subsequent heating." "These results suggested another line of enquiry, wiz:--the combining behavior of the acid, without the aicl of pepsin, at the ordinary temperature as well as at higher temperatures. The amount of acid combining at the ordinary temperatures may in many cases be found by simple titration, while for higher temperatures other means may be employed.

At the ordinary temperatures many dilute acids combine with casein as with other proteins to form salts, and the amount of acid so held is definite and constant. By warming, however, or by prolonged contact, the acids lead to the formation of hydrolysis products, some of which as amino acids, are strong enough to hold considerable quantities of the acids used as the combining and hydrolyzing agents. It was shown in the last papers quoted that the amount of hydrochloric acid held in this way is about what might be expected from the character of the amino acid groups probably developed. But in the present inquiry we are concerned with the activity of the acids when not assisted by the digesting power of the pepsin, and the first experiments were made with $\mathrm{N} / \mathrm{IO}$ hydrochloric acid at the ordinary temperature, followed by some in which the combination was effected by heat.

Hydrochloric Acid. - A series of tests was made, using always 5 grams of pure casein prepared by the Hammarsten process and varying amounts of the weak acid, with water enough to make up always roo cubic centimeters. The mixtures of weak acid and casein were allowed to stand

${ }_{1}^{1}$ This Journal, 27, 363; 28, 372.

2 Ibial. 29, 223; 29, 295. 